\title{
Policy of Sultan of Langkat in Managing and Keeping the Environment of Langkat Area
}

\author{
Ratna $^{1}$, Suprayitno ${ }^{1}$, Farida Hanum Ritonga ${ }^{1}$, Handoko ${ }^{2}$ \\ ${ }^{1}$ Lecturer of History Science, University of North Sumatra \\ ${ }^{2}$ Alumni of Masters of History Science, University of North Sumatra \\ ratna4@usu.ac.id
}

\begin{abstract}
Long before modern regulations on the environment were implemented, Malay sultanates on the East Coast of Sumatra had made regulations that protect, manage and preserve the environment within their territories. One of the sultanates that has these regulations is the Langkat Sultanate. Environmental management in the Langkat Sultanate includes protection and management of forests, river protection, and prohibition of logging certain types of trees and protecting animals. How does the Sultan of Langkat protect and manage the environment? What kind of environment is protected and managed by the Sultan of Langkat? These questions will be discussed in writing. This paper uses archival sources and publications during the colonial government in the Netherlands in Langkat and the rules of the Sultan of Langkat itself about environmental management and protection. This paper aims to describe how traditional governance including the Langkat Sultanate has managed and maintained the environment well.
\end{abstract}

Keywords : enviroment; Sultan Langkat; management; preservation

\section{Introduction}

Environment is a combination of physical conditions that include the state of natural resources such as land, water, solar energy, minerals, and flora and fauna that grow on land and in the oceans, with institutions that include human creation such as the decision on how to use the physical environment. The environment in Indonesia is often also called "the environment". The same thing was stated in Law No. 32 of 2009 concerning Environmental Management. Definition of Environment is the unity of space with all objects, power, circumstances, and living things, including humans, and behavior, which affects the continuity of life and the welfare of humans and other living things and can affect their lives. ${ }^{1}$

Understanding the environment can be said as everything that exists around humans or living things that have reciprocal and complex relationships and influence each other between one component and other components. The definition of environment that is more in-depth according to Law No. 32 of 2009 is the unity of space with all objects or the unity of living things including human beings and all their behavior in order to sustain the lives and welfare of humans and other living beings around them. ${ }^{2}$ Long before regional laws or regulations were issued by central and regional governments, traditional governments in Indonesia, especially the Langkat Sultanate, had policies in environmental management. The Langkat Sultanate is one of the largest Malay Sultanates in East Sumatra.

\footnotetext{
${ }^{1}$ N.H.T Siahaan, Hukum lingkungan dan ekologi pembangunan, Jakarta: Erlangga, 2004, Page 4

2 Ibid., page 5
} 
The assumption that the sultan as the owner of the land caused the entrepreneurs to only deal with the sultan if he needed plantation land. In order to obtain the plantation land concession, the entrepreneurs paid the land rent per year to the sultan as compensation. ${ }^{3}$ Fertile land and favorable results have made foreign investors vying to establish plantations in Langkat. Until 1875 there had been seven modernization in the Langkat area. The higher the profit from the results of these plantations, the higher the income earned by Sultan Langkat. Even though the sultan allowed the businessmen to open plantation land that needed a lot of land, the sultan still tried to keep his environment from being damaged. There are several forest areas and several types of trees that should not be damaged by the sultan for reasons to protect the environment. In addition to forest and tree areas, the sultan also tried to maintain the watershed in the Langkat. However, the policies of the Sultan of Langkat to protect his environment are not yet well known.

\section{Research Method}

The technique of collecting primary and secondary data is done through observation or survey directly to the object of research. In addition, supporting data collection is carried out in libraries and institutions which are considered to be a source of data in research, for example to the Langkat District Government Office; North Sumatea Provincial Library and Langkat Regency Library; and research that has been carried out; and publications / magazines related to the environment. The research material comes from data sources obtained directly from the results of observations / surveys in the form of data found in Langkat Regency and from secondary data. There are several primary data that need to be investigated, which become a collection of individuals that contain predetermined characteristics. In addition to looking for written data, this study also uses oral sources by interviewing several informants who are considered competent towards environmental management in Langkat.

The method of data analysis uses the Historical analysis method which aims to study and explore facts or experiences and developments of the past by trying to draw conclusions and try to make an interpretation of the data from the event. The main data includes data relating to the responses, desires and opinions of the local community towards environmental management and preservation. Adapundata supporters were obtained from various government agencies that have the authority and associated with the development of tourism in Langkat Regency. This data collection is done to obtain documents, archives, maps, reports, etc. as reference material. The institution that has a connection with the management and safeguarding of the environment in Langkat Regency is the Office of the Environment of North Sumatra Province.

\section{Discussion}

The Langkat Sultanate is one of the largest Malay Sultanates in East Sumatra. The establishment of the Langkat Sultanate dates back to the 16th century. However, the

\footnotetext{
${ }^{3}$ Anthony Reid, Perjuangan Rakyat : Revolusi dan Hancurnya Kerajaan di Sumatera Timur, Jakarta : Pustaka Sinar Harapan. 1987, page 87-88. 
existence of the Langkat Sultanate and the existence of a leader called the sultan only existed since 1840, especially after Sultan Musa came to power. At that time, the understanding of the sultan was not only a government leader and ulil amri, but also as a traditional leader. During the leadership of Sultan Musa, the life of nobles in the Langkat Sultanate was still simple. The palace which is located in Pati City (Tanjung Pura now) is still in the form of a wooden house on stilts. His palace is opposite the Batang Durian River which is located behind the Azizi Mosque. ${ }^{4}$

At that time the Langkat Sultanate was between the Deli and Tamiang Sultanates with the following boundaries to the east: bordering Landschap Deli and Serdang, to the west: bordering Aceh Residency, north and south: bordering Afdeeling Simalungun and Tanah Karo. The first contact between the Langkat Sultanate and Dutch Colonialism began when Sultan Musa came to power, namely after the traktaat Siak ${ }^{5}$. was signed. In February 1862 Sultan Musa openly came to Siak to ask for help from the Netherlands to secure his territory from frequent uprisings in his area, as well as threats from Aceh. Therefore, it is not surprising when E. Netscher made his first expedition to East Sumatra in order to tie the kingdoms in East Sumatra under Dutch rule, in Langkat Netscher there were no obstacles. ${ }^{6}$

Netscher's conquest of the kings of East Sumatra coincided with the development of an online business which was pioneered by Nienhuys. That is, the entanglement of Malay sultans in colonial rule, made it easier for planters to acquire the plantation land. ${ }^{7}$ Just like other areas of the East Sumatra Malay Sultanate, plantation businesses turned out to be beneficial for the sultanate. The assumption that the sultan as the owner of the land caused the entrepreneurs to only deal with the sultan if he needed plantation land. In order to obtain the plantation land concession, the entrepreneurs paid the land rent per year to the sultan as compensation. ${ }^{8}$

Fertile land and favorable results make foreign investors compete to establish plantations there. The higher the profits from the results of these plantations, the higher the income obtained by the Sultan of Langkat. According to the planters get land concessions with the most favorable conditions, and run "facilitation payments" and the system of bribes and gratuities. granting to the Malay elite is far cheaper than paying taxes to the Dutch Colonial government. For governor, these sultans not only became a pretext for the presence of his power, but also became a cheap intermediary for curbing very complex and autonomous social structures of the Batak tribes. In addition, these sultans can be used as

\footnotetext{
${ }^{4}$ Zainal Arifin Aka, Riwayat Tengku Amir Hamzah : Cinta Tergadai, Kasih Tak Sampai, Langkat : Dewan Kesenian Langkat, 2002, page 5.

${ }^{5}$ Traktaat Siak is an agreement between the Netherlands and Siak signed on February 1, 1858. One of its contents was Siak recognizing Dutch sovereignty and including the kingdoms on the east coast of Sumatra, such as Deli, Serdang, Langkat, and Tamiang.

${ }^{6}$ The first expedition was carried out in early August 1862. At that time, Serdang and Deli did not want to immediately sign the agreement with the Dutch because they did not want to submit to Siak's authority. Finally the Dutch Colonial Government fulfilled their request by removing the sentence that recognized Siak's sovereignty, and fully recognized Dutch sovereignty. However, this first expedition experienced obstacles because even though they already admitted, but in practice these kings still defied the Dutch.

7 Langkat is one of the targets of planters in order to expand the region of modernization. Then the onderneming business in Langkat only began around 1871. In 1872 there were around 13 ondememing, while in Serdang and Langkat there were 1 onderneming. Look, Mohammad Said, op. cit., p. 44.
}

${ }^{8}$ Anthony Reid, loc. cit. 
shields to cover up the actions of the governor who do not please the people. ${ }^{9}$ Even so, the Dutch Colonial power with its plantation economic system had increased their prestige and prosperity as aristocratic groups. ${ }^{10}$

Until 1875, there were seven onderneming in the Langkat area. This number of onderneming is increasing steadily. In the 1930s, there were 38 onderneming in Langkat. In 1883 an oil field was discovered in Telaga Said, Langkat. For the development of the oil industry, the Sultan of Langkat (Sultan Musa) had granted 500 thousand concessions to the mining company (Bataafsch Petroleum Matschappij). In 1885, the mining company again obtained extensive concessions covering the area of Sei Lepan, Sentang Hill to the Base of the Army.

Even though the sultan allowed the businessmen to open plantation land that needed a lot of land, the sultan still tried to keep his environment from being damaged. Environmental protection regulations are stipulated by deliberation by the Sultan Langkat with the datuk / kejeruan referring to Dutch laws during the time of Sultan Tengku Abdul Azis, which then continued with Sultan Tengku Machmud. There are several forest areas and several types of trees that should not be damaged by the sultan for reasons to protect the environment. In addition to forest and tree areas, the sultan also tried to maintain the watershed in the Langkat. However, the policies of the Sultan of Langkat to protect his environment are not yet well known.

From the explanation above, it can be categorized that the elements of the environment each have criteria or types. Types of environment in general are groups or ecosystem units such as forest areas, waters, and animals. Based on this also, the environment in Langkat includes types such as primary forest or protected forests, mangrove areas, animal groups, river ecology and so on.

The types of environment protected by Sultan Langkat are as follows:

1. Primary Forest Areas such as the Sikundur area which is now included in the Gunung Leuser National Park area.

2. Toengkam Forest Area in the Bukit Lawang or Bahrok Langkat area.

3. Mangrove Forest Areas in the West Berandan, Besitang, and North Pura Areas.

4. Ecological areas of rivers or watersheds such as the Besitang River, Batang Serangan River and others

5. As well as several animal groups reptiles, parasites, mammals and other aquatic animals.

Environments that are considered or prohibited to be damaged are certain forest areas, certain types of plants, and other environmental ecologies such as rivers, seas, and estuaries, including their biota such as fish and other types of fauna. The land that is consecrated if there is a type of tree that is prohibited by the Sultan of Langkat to be cut down, the planter must obey it. If it is found that a tree is cut down, the plantation must pay a fine determined by the Large Density of the Langkat Sultanate.

The types of protected environment have been determined by the Sultan of Langkat, so for protection of the environment contained in the regulations of the Sultan of Langkat. These regulations contain prohibitions, penalties for people or people who violate in the form of imprisonment and fines. Penalty penalties and fines depend on the violations made, for cases

\footnotetext{
${ }^{9}$ Ibid.

${ }^{10}$ Suprayitno, Mencoba (Lagi) Menjadi Indonesia, Yogyakarta : Yayasan Untuk Indonesia, 2001, page. 21.
} 
of violation of tree felling in contrast to cases of forest destruction as well as cases of riverbank destruction that differ from poisoning fish in the river. The penalties were also different based on the case, there were cases that were resolved at a small density (kampong) and there were also cases that were settled in large densities in Tanjung Pura.

Regulations for maintaining and preserving the forests specified in the Langkat Sultanate, the Sultan of Langkat in 1915 issued a regulation that the community was prohibited from cutting and carrying trees and collecting and carrying wood from within the forest. This prohibition is excluded if the community only uses the wood for firewood, plantation fences and tools provided that the diameter of the wood must not exceed $10 \mathrm{~cm}$. In addition to cutting down trees and collecting wood, Sultan Langkat also prohibits collecting bark without the permission of the sultan. ${ }^{11}$

Another regulation for forest conservation and forestry in Langkat is the ban on land clearing for farming, pasturing pets such as horses, buffaloes and other pets and burning forests. If the field or plantation land is close to the forests, then the combustion can only be 1 $\mathrm{KM}$ from the distance of the forest and if it is to burn the forest it is necessary to be protected by the landowner. For people who break the rules to preserve and conserve the forest then, a fine of $f 100$ or a jail term of 3 months. For those who carry firewood from a forbidden forest then the timber will be confiscated and charged a penalty of $f 15$ or a sentence of confinement for fourteen days. ${ }^{12}$

The forests that are in the forests of the Langkat Sultanate are areas or areas of the Great Sikoendoer forest with an area of approximately 14,000 HA, Small Sikoendoer with an area of approximately 2,000 HA, Toengkam with an area of approximately 2,000 HA, as well as the area of Northwest Brandan forest with wide area - 17,000 HA. ${ }^{13}$ Specifically, North Brandan's forest area is a mangrove forest area that can not be cut down and destroyed by both the sultanate and the people outside the sultanate. ${ }^{14}$

Not only forest areas, other ecological environment in the forests, such as rivers, rivers, marshes and fauna should not be destroyed, including capturing wildlife in them. For example, a ban to damage the river embankment by hoeing and burning bushes on the river embankment. If the rule is violated it will be charged a penalty of $f 100$ and a jail term of one month. ${ }^{15}$ For the wildlife, the Langkat Sultanate also imposes a policy to prohibit arrest and kill animals in the forests. Animals that are forbidden to be captured and killed are orangutans, birds, and lactating animals that contain 62 animals including deer, wild cows, deer, and so forth. For poultry or birds, it is prohibited to take eggs and damage the nest. If there is a violation of this rule, it will be confiscated by the catching animal. The surviving catching animals will be released back into the forest, if the catching animals are dead then the catch will be punished for 1 or 2 days. ${ }^{16}$

There are several policies of the sultanate that have been made up to date are still preserved and preserved. Despite the different forms, areas previously protected by the Sultan of Langkat are still in sight. For example, the area of Sikundur forest which is currently in the

\footnotetext{
${ }^{11}$ Zelfbestuurbesluiten Langkat ddo 22 Januari 1916.

${ }^{12}$ Zelfbestuurbes/uiten Langkat ddo 22 Januari 1916.

${ }^{13}$ Zelfbestuurbesluiten Langkat ddo 09 December 1915.

${ }^{14}$ Zelfbestuurbesluiten Langkat ddo 20 Januari 1916.

${ }^{15}$ Zelfbestuurbesluiten Langkat ddo 22 September 1924.

${ }^{16}$ Zelfbestuurbes/uiten Langkat ddo 22 Agustus 1928.

DOI : https://doi.org/10.33258/birci.v2i1.16 
area of Gunung Leuser National Park is still maintained by the public and its guardian status is at the national level under the Ministry of Environment not under the auspices of the government of Langkat or North Sumatra Provincial Government.

In addition to primary forest areas, mangrove forest areas are protected even though they were previously damaged due to the opening of oil palm plantation areas, but for the self-awareness and awareness of the environment surrounding the importance of environmental stability, the people in the West Berandan District began planting and preserving mangrove forest areas. The mangrove forest area in Langkat is self-managed by the community and some are managed by the government through the North Sumatra Provincial Environment Office in collaboration with the surrounding people. The managed area is now managed by community groups or Non-Governmental Organizations such as Mekar and Sustainable groups.

\section{Conclusion}

Conservation of the environment has the connotation that the living environment must be maintained as it is, while the environment is actually utilized in the framework of development. This means that the environment of life experiences a process of change. In the process of change this needs to be maintained so that the environment is still able to support a normal life. Even though the sultan allowed the businessmen to open plantation land which had a lot of land, the sultan still tried to keep the environment from being damaged. There are several forest areas and several types of trees that should not be damaged by the sultan for reasons to protect the environment. In addition to forest and tree areas, the sultan also tried to maintain the watershed in the Langkat. However, the policies of the Sultan of Langkat to protect his environment are not yet well known.

\section{Acknowledgement}

This article couldn't have been possible thanks to funding of "Penelitian TALENTA USU skema Penelitian Dasar". We also thanks to Lembaga Penelitan USU which has accommodated this research. Besides that, we also thanks to Arsip Nasional Republik Indonesia because the sources of this article are widely available there.

\section{References}

Aka, Zainal Arifin, 2002, Riwayat Tengku Amir Hamzah: Cinta Tergadai, Kasih Tak Sampai, Langkat : Dewan Kesenian Langkat.

Anseb, 1938, De Grond van Deli, Medan: Varekamp \& Co.

Arsip Algemene Secretarie Grote Bundel Besluiten No. 2665.

Basayarshah II, Tuanku Luckman Sinar, Bangun dan Runtuhnya Kerajaan Melayu di Sumatera Timur.

Breman, Jan, 1997, Menjinakkan Sang Kuli: Politik Kolonial, Tuan Kebun, dan Kuli di Sumatera Timur pada Awal Abad ke-20, Jakarta: Pustaka Utama Grafiti danKITLV.

Djamin, Djanius, Pengawasaan dan pelaksanaan undang undang lingkungan hidup, Jakarta: Yayasan Obor Indonesia, 2007. 
Fatimah, 1985, "Pengaruh Sosial Ekonomis Perkebunan Tembakau Terhadap Masyarakat di Sumatera Timur" Tesis belum diterbitkan, Yogyakarta: Universitas Gadjah Mada.

Hamid A. Datuk O.K. Abdul, 2011, Langkat Mendai Tuah Berseri, Medan: Badan Perpustakaan, Arsip, dan Dokumentasi Provinsi Sumatera Utara.

Husein, Harun M., Lingkungan Hidup, Jakarta: Bumi Aksara, 2000.

Husin, Djohar Arifin, 2012, Sejarah Kesultanan Langkat, Langkat: Yayasan Bangun Langkat Sejahtera, 2012.

Pelzer, Karl J., 1985,Toean Keboen dan Petani: Politik Kolonial dan Perjuangan Agraria di Sumatera Timur 1863-1947, (translated by J. Rumbo) Jakarta: Sinar Harapan Publisher.

Rahmadi, Takdir, Hukum Lingkungan di Indonesia, Jakarta: Raja Grafindo Persada, 2012.

Reid, Anthony, Perjuangan Rakyat : Revolusi dan Hancurnya Kerajaan di Sumatera Timur, Jakarta : Sinar Harapan Library. 1987.

Said, Mohammad, Kuli Kontrak Tempo Dulu : Dengan Derita dan Kemarahannya, Medan : Waspada, 1977.

Siahaan, N.H.T , Hukum lingkungan dan ekologi pembangunan, Jakarta: Erlangga, 2004.

Stoler, Ann Laura, 2005, Kapitalisme dan Konfrontasi di Sabuk Perkebunan Sumatera (1870 -1979), Yogyakarta: Karsa.

Sumarno, Edi, "Mundurnya Kota Pelabuhan Tradisional di Sumatera Timur pada Periode Kolonial" in Historisme Edisi No.22/Tahun XI/Agustus 2006.

Suprayitno, 2001, Mencoba (Lagi) Menjadi Indonesia, Yogyakarta : Yayasan Untuk Indonesia.

Volker, T., 1918, Van Oerbosch Tot Cultuurgebied: Een Schetsvan de Beteekenis van de Tabak, de Andere Cultures, en de Industrie ter Oostkust van Sumatra, Medan, De Deli Planters Vereeniging.

Wie, Thee Kian, 1977, Plantation Agriculture and Export Growth an Economic History of East Sumatra 1863-1942. Jakarta: National of Institute of Economic and Social Research (LEKNAS - LIPI).

Zelfbestuurbesluiten Langkat ddo 09 December 1915.

Zelfbestuurbesluiten Langkat ddo 20 Januari 1916.

Zelfbestuurbesluiten Langkat ddo 22 Januari 1916.

Zelfbestuurbesluiten Langkat ddo 22 September 1924.

Zelfbestuurbesluiten Langkat ddo 22 Agustus 1928. 